\title{
4. CENOZOIC OSTRACODA FROM GUYOTS IN THE WESTERN PACIFIC: HOLES 865B AND 866B (LEG 143) ${ }^{1}$
}

\author{
Ian Boomer ${ }^{2}$ and Robin Whatley ${ }^{2}$
}

\begin{abstract}
The Cenozoic Ostracoda recovered from two guyots in the western Pacific Ocean are investigated. A high percentage of the taxa have been restricted to the individual guyots, thus supporting recent evidence that high levels of endemism documented on these bathymetrically isolated sites are real and do not simply reflect lack of knowledge in that region. Changes in the Ostracoda assemblages (diversity, abundance, dominance, endemism, faunal turnover) are detailed, together with an analysis of the evolution of the major groups recovered. Biostratigraphical interpretations are limited as a result of the high incidence of endemic taxa. Preliminary evidence is emerging from these Ostracoda, however, of regional "events" in the Ostracoda assemblages that can be traced on different guyots.
\end{abstract}

\section{INTRODUCTION}

As our knowledge of deep-sea Ostracoda has advanced, it has become apparent that there exists, in modern and Cenozoic oceans, a widespread, pandemic component as well as regional, more endemic taxa (Whatley and Ayress, 1988; Coles et al., 1990). Furthermore, patterns of migration and centers of evolutionary radiation have been identified (Whatley et al., 1984, 1986). Much of the pandemic fauna is absent from guyots whose assemblages are often dominated by species that have evolved in situ and that are restricted to that site. These latter endemic species dominate most Cenozoic and modern guyot assemblages.

To a large extent, podocopid Ostracoda are bathymetrically controlled in their distribution (although not directly so), and assemblages of particular Ostracoda have been associated with different water masses (Dingle et al., 1990). Benthic Ostracoda have no pelagic larval stage and, therefore, their migration is determined by individual locomotory capabilities (active element) and by the nature of prevailing bottom currents (passive element). Their carbonate carapaces effectively exclude them from depths below the lysocline and, in general, their migration must take place along routes above this level. Chance migration events, when transported by other organisms (in some cases, against existing current directions) cannot be ruled out, but such occurrences are not considered to be significant. Ostracoda living on the summits of guyots are denied the benefits of floating weed, wood, or birds as mechanisms assisting their migration.

A number of recent unpublished studies have identified distinct endemic elements to the Cenozoic Ostracoda assemblages recovered from Indo-Pacific guyot sites (Downing, 1985; Ayress, 1988; J.G. Larwood, unpubl. data, 1992). A number of studies based on nonguyot sites from the Indo-Pacific region have also provided comparative data (Ainsworth, 1982; Smith, 1983; Dainty, 1984; Millson, 1987). This research has been summarized by Larwood and Whatley (1993). Endemic species are those known only from one site, they have not been recorded from other guyots, nor from the surrounding abyssal plains. The level of endemism in a sample is calculated as the percentage of recorded and lazarus species (i.e., those apparently absent from a given sample) known only from that site. These values must inevitably reflect the extent of our knowledge of deep-sea Ostracoda in the region of study. The fewer the sites available for study,

\footnotetext{
' Winterer, E.L., Sager, W.W., Firth, J.V., and Sinton, J.M. (Eds.), 1995, Proc. ODP, Sci. Results, 143: College Station, TX (Ocean Drilling Program).

${ }^{2}$ Institute of Earth Studies, University of Wales, Aberystwyth, Dyfed, SY23 3DB, United Kingdom.
}

the greater the likelihood that some of the recorded taxa will appear to be endemic. This is particularly true in this study and must be considered when interpreting our results. Apparently, as more Pacific guyots are studied, endemism levels remain higher than those for nonguyot deep-sea assemblages in the region. As the submarine summits of these guyots are commonly at a water depth of about $1500 \mathrm{~m}$, it is perhaps surprising that levels of endemism are not higher than those observed. We can deduce that migration onto the guyots, by whatever means, does occur, despite the bathymetrical isolation of these sites.

Larwood and Whatley (1993) noted that endemism values for the Pliocene-Pleistocene interval of a number of nonguyot Pacific deepsea sites are in the range of $5 \%$ to $25 \%$, compared with $50 \%$ to $60 \%$ for Horizon Guyot (DSDP Sites 200/202) and Ita Mai Tai Guyot (DSDP Sites 44/171) during the same interval. The high levels of endemism encountered at these sites, when compared with local nonguyot assemblages, reflect the bathymetric isolation of the guyot summits, particularly those surrounded by abyssal plains that lie below the lysocline. Limited migration onto the guyots results in a high degree of evolution in isolation, similar to that recorded in the terrestrial floras and faunas of oceanic islands.

\section{CENOZOIC EVOLUTION OF OSTRACODA ON PACIFIC GUYOTS}

Previous studies from Ita Mai Tai (Downing, 1985; Ayress, 1988; J.G. Larwood, unpubl. data, 1992) and Horizon (J.G. Larwood, unpubl. data, 1992) guyots in the Mid-Pacific Mountains and a number of guyots in the Emperor Seamount Chain (Larwood and Whatley, 1993; J.G. Larwood, unpubl. data, 1992.) indicate that, in some cases, the Late Cretaceous shallow-water Ostracoda of these sites initially adapted to the subsequent deepening phase. Subsidence of the guyot summits eventually stabilized, and pelagic sediments began to accumulate during the earliest Cenozoic.

The inception of the thermocline at approximately $40 \mathrm{Ma}$ (Benson, 1975 ) initiated a temperature barrier, denying access for many organisms between the upper thermospheric and the lower psychrospheric layers of the world ocean. The absence of such a barrier during Late Cretaceous and early Paleogene time allowed otherwise thermophylic taxa to adapt, albeit slowly, to the cold, deeper water conditions as the guyots on which they lived slowly subsided. One taxon to achieve this was Cytherelloidea, as witnessed on Horizon Guyot (Larwood and Whatley, 1993; and ODP Hole 865B, this chapter), a genus generally noted for its preference for warm-water conditions. In general, however, the shallow-water assemblages were replaced by typical deep-sea 
faunas (e.g., on Suiko Guyot [DSDP Site 433], Emperor Seamount Chain), while, in some cases, no Ostracoda have been recorded after the disappearance of the shallow-water taxa (e.g., Ojin [DSDP Site 430] and Koko [DSDP Site 308] guyots in the Emperor Seamount Chain; J.G. Larwood, unpubl. data, 1992).

\section{METHODS}

Two sites drilled during Leg 143 were investigated. Twenty-nine samples $\left(50 \mathrm{~cm}^{3} \mathrm{each}\right)$ were investigated from Hole $865 \mathrm{~B}$ and another 10 samples from Hole $866 \mathrm{~B}$. All samples were washed through a 200-mesh sieve to remove the mud fraction and then air-dried; they were then dry-sieved through 60- and 100-mesh sieves. The largest two fractions were completely picked (i.e., all Ostracoda $>125 \mathrm{~m}$ ) under a binocular microscope and arranged in faunal slides. The number of left and right valves of each species in a sample was recorded, and the greater number taken as an estimate of the minimum number of individuals present in that sample. It is these values that are given in the distribution range charts (Tables 1 and 2). Figured specimens were coated with gold and photographed under the Cambridge 140 scanning electron microscope (SEM) at Aberystwyth. All figured specimens and faunal slides are held in the collections of the Micropalaeontology Museum, University of Wales, Aberystwyth.

\section{SITE 865}

From Hole $865 \mathrm{~B}$ on Allison Guyot $\left(18^{\circ} 26.41^{\prime} \mathrm{N}, 179^{\circ} 33.33^{\prime} \mathrm{W}\right.$, Fig. 1), $139 \mathrm{~m}$ of Quaternary to lower Paleocene nannofossil ooze and foraminiferal sand was cored. Most of this carbonate sequence, representing the mid-Paleocene to late Eocene interval, probably formed as the guyot passed through the high productivity zone of the equatorial region. The high proportion of sand-grade sediments suggests the winnowing action of submarine currents. The lower Paleocene-lower Oligocene sequence is followed by a hiatus, with the next youngest sediments belonging to the lower Miocene.

The abundance of Ostracoda throughout much of the sequence is good. Most of the samples yielded approximately 100 individuals, although the NP9-NP10 interval (uppermost Paleocene-upper Eocene) was somewhat impoverished. Conversely, samples in the NP18NP21 interval (upper Eocene-lower Oligocene) yielded between 300 and 700 individuals (Fig. 2A). The stratigraphical ranges of the Ostracoda recovered are presented in Table 1.

Simple species diversity of Ostracoda (i.e., number of species) has been calculated in two ways. First, as the number of species recorded in a given sample (i.e., the recorded diversity) and, second, as the recorded diversity plus those "Lazarus taxa" known to occur stratigraphically above and below the current sample, but that are temporarily absent from the assemblage, possibly as a result of sample inadequacy. Both values were plotted on a simple species diversity graph (Fig. 2B). Here, we shall consider only the "recorded + lazarus taxa" diversity calculation, as this provides a more accurate assessment of biological diversity for the interval.

Diversity in the earliest sediments investigated (Zone NP4) is low, with only 11 species. This increases to 24 species in the upper Paleocene (NP6) and decreases to a low of 15 during the Paleocene/Eocene boundary interval. Subsequently, species diversity recovers, then increases continually throughout the lower, middle, and upper Eocene to reach a peak of 45 species in the lower Oligocene (NP21). The two youngest samples investigated from the lower Miocene (NN4-NN5) indicate there was a large decrease in species diversity following the latest Paleogene hiatus. This unconformity is also apparent in the graph of species originations (first appearances) and extinctions (last appearances) plotted for this site (Fig. 2D). Note that, as specific diversity increases, the level of specific endemism (Fig. 2C) remains stable at about $50 \%$. This indicates that as species were continuously evolving in isolation, the appearance of the daughter species was accompanied by the extinction of the parent species (parapatric spe- ciation): this type of speciation has also been witnessed at other guyot sites (Larwood and Whatley, 1993).

The graph of species extinctions and originations (Fig. 2D) shows a higher level of origination than extinction throughout much of the sequence. Twenty-four of the species recorded in the uppermost Paleogene sample (Section 143-865B-2H-5, 100-106 cm) are not recorded in the next younger sample following the hiatus. A relatively higher number of species originations is recorded in the upper Eocene and lower Oligocene assemblages than for much of the Eocene and Paleocene sequences.

The high level of originations at the base of the sequence (Fig. 2D) results in part from the nature of the graph, where all species encountered for the first time have been recorded. Note, however, that the lower part of the upper Paleocene sequences is also marked by a high extinction rate, indicating an increased rate of faunal turnover. This probably reflects a combination of initial colonization by deep-sea taxa, together with increased levels of evolution in situ.

\section{EVOLUTION OF OSTRACODA, HOLE 865B}

\section{Lower Paleocene-Upper Paleocene}

The lower Paleocene and lowermost upper Paleocene samples from Hole $865 \mathrm{~B}$ are dominated by the platycopid genera, Cytherella and Cytherelloidea (Fig. 3B). The latter genus is thermophylic and often indicates shallow, warm-water conditions. Its occurrence in these deep-sea samples probably indicates the adaptation of a single species from the shallow-water, or emergent, phase of the guyot, with the organism having slowly adjusted to colder, deeper water conditions. Such an adaptation would have been more easily achieved during the Paleocene, when the thermocline did not act as a temperature barrier; furthermore, during this period, the summit of the guyot would have been much shallower and at a lower latitude. One of the few species recorded in this interval to have been recorded previously is Profundobythere volans (Neale, 1975), originally recorded from the Upper Cretaceous of Western Australia. This occurrence indicates the widespread distribution achieved by some species of Ostracoda during the late Mesozoic-early Cenozoic interval.

The high level of originations in this interval leads to an initial diversity peak (Fig. 2B) concomitant with a decrease in the percentage of abundance of the Platycopina (Cytherella and Cytherelloidea), which had peaked in the lower Paleocene at about $80 \%$ of the total fauna. The Platycopina never again achieved such dominance in this sequence. The dominance value (defined as the percentage of the total fauna constituted by the single most abundant species) in this lowest part of the sequence peaks three times (Fig. 3A). Average dominance values for normal marine assemblages are about $30 \%$ to $50 \%$ (authors, unpubl. data). This average value holds true in much of the sequence, except for the three peaks of $65 \%$ to $90 \%$, which correspond to successive dominance by the Platycopina, followed by Krithe spp. and, finally, the bythocytherid genus Pariceratina in the Paleocene and lowermost Eocene intervals. These three successive peak values in the abundance of Platycopina, Krithe, and Pariceratina may indicate some degree of biological stress within the Ostracoda communities, possibly as a result of external forces, either physical or chemical. Indeed, such stress may record the passage of the guyot summit through the oxygen minimum zone of the Pacific Ocean during the earliest Cenozoic.

The genus Krithe dominates many of the upper Paleocene assemblages (Fig. 3C). During this interval, diversity declines, as does the abundance of Ostracoda (i.e., number of specimens recovered). The dominance of Krithe reflects a similarity with many other Cenozoic deep-sea assemblages. We reject the hypotheses put forward by Peypouquet $(1975,1977,1979)$ regarding the relationship between the morphology of individual Krithe "species" and dissolved oxygen levels in the ambient water.

As diversity and abundance of Ostracoda decline at the Paleocene/ Eocene boundary, the genus Pariceratina dominates the assemblages 


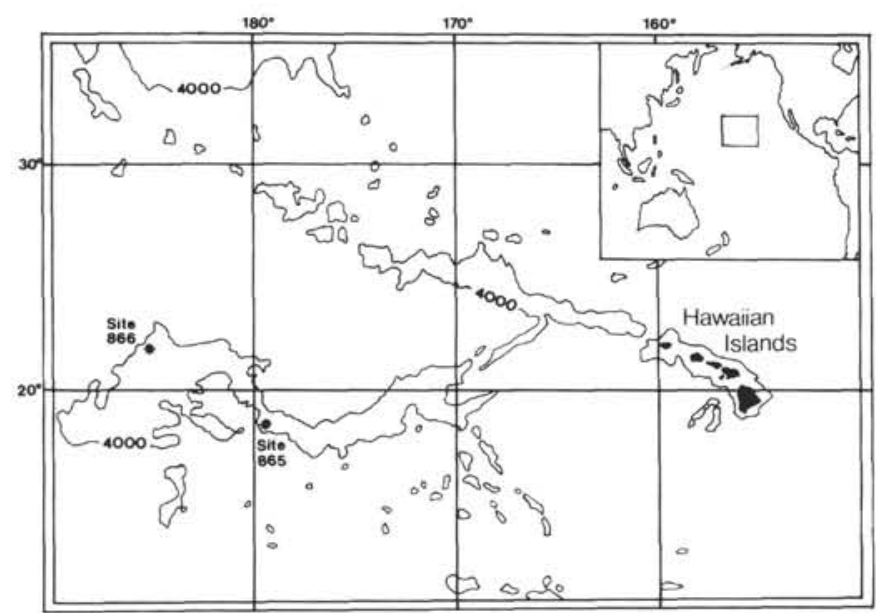

Figure 1. Location map of Holes 865B and 866B, Leg 143, with $4000 \mathrm{~m}$ depth contour marked.

(Fig. 3D), represented here by a single species, Pariceratina sp. 1. This species is recorded throughout the sequence and is also known to occur at Hole 866B, as well as at a number of other Pacific Ocean sites (Millson, 1987; J.G. Larwood, unpubl. data, 1992; authors, unpubl. data). Neale (1975) recorded Cretaceratina trispinosa from the Upper Cretaceous of Western Australia, which is similar in form to Pariceratina sp. 1. Following the interval dominated by Pariceratina $\mathrm{sp} .1$, the absolute abundance and diversity of the Ostracoda show an increase.

Global paleoceanographical events at the Paleocene/Eocene boundary affected benthic deep-sea foraminiferal assemblages (Eldholm and Thomas, 1993; Miller et al., 1987; Rea et al., 1990; Thomas, 1990, 1992). These studies indicate that a major paleoceanographical change occurred, possibly the result of a conversion to a salinity-driven oceanic circulation system. It has been suggested that this resulted from a climatic response to large-scale tectonic events in the North Atlantic (Rea et al., 1990). Irrespective of the cause of these changes, it is apparent from this study that benthic Ostracoda on the mid-Pacific guyots were not isolated from these events.

\section{Lower and Middle Eocene}

This interval is marked by a steady increase in diversity and a stable rate of faunal turnover. Dominance levels are stable and lower than those recorded in the older part of the sequence. Coincident with the decline in dominance of Pariceratina in the lower to middle Eocene is an increase in abundance of the Platycopina. Initially, they constitute almost $40 \%$ of the assemblage; however, from about Zone NP12 upward, the Platycopina steadily decline in abundance through the section, although this trend shows a short-term reverse in the upper Eocene.

Two Krithe species and four platycopid species are present in the Paleocene samples, but none of these range into the Eocene. Subsequently, three new species of Krithe and three of Cytherella appear in the Eocene and the younger part of the sequence. It would appear that an important evolutionary event occurred within these groups during the Paleocene/Eocene boundary interval, a period typified in this section by low abundance, low diversity assemblages dominated by Pariceratina. The initial reappearance of the Platycopina and the decline in importance of Pariceratina coincide with the complete absence of Krithe species. This is remarkable in that Krithe had previously constituted almost $60 \%$ of the fauna. Krithe subsequently reappears in the uppermost middle Eocene and gradually increases in abundance throughout the rest of the sequence.

It is possible that the increased abundance of Krithe together with the concomitant decrease in Platycopina suggest a replacement of the latter by the former. Platycopids, as filter feeders, are known to have
A

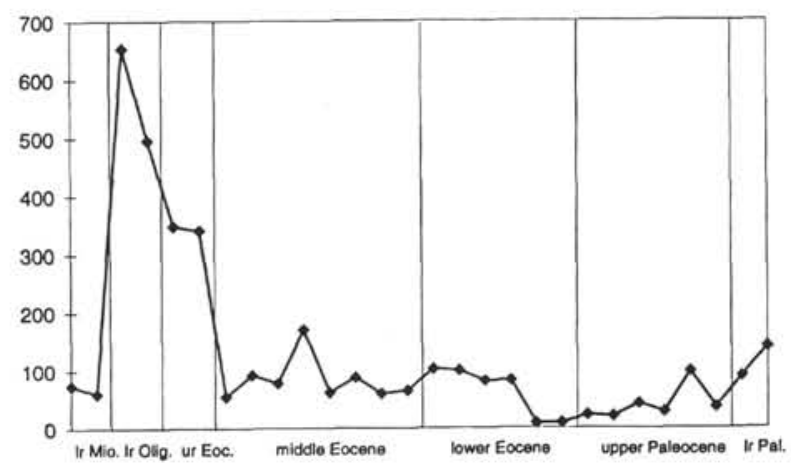

B

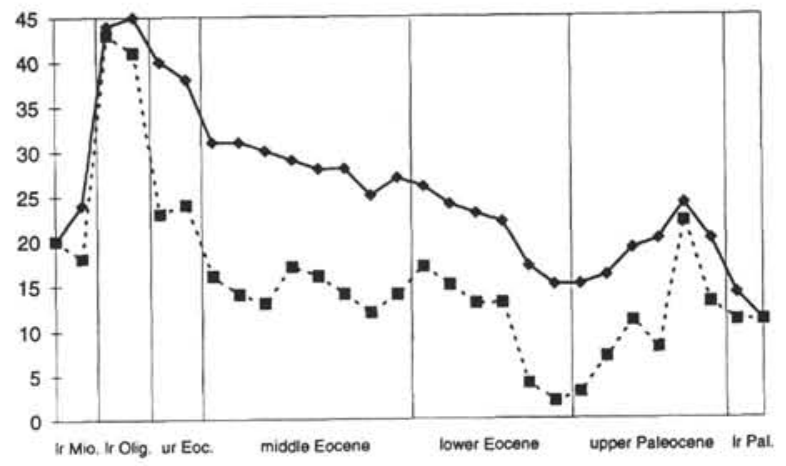

C

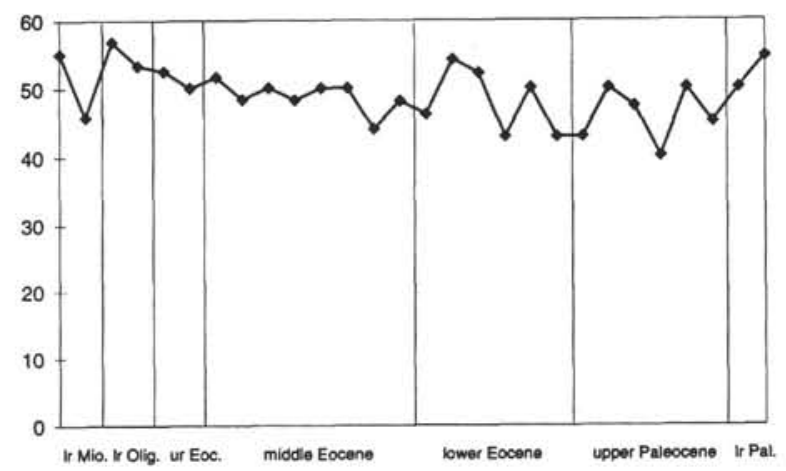

D

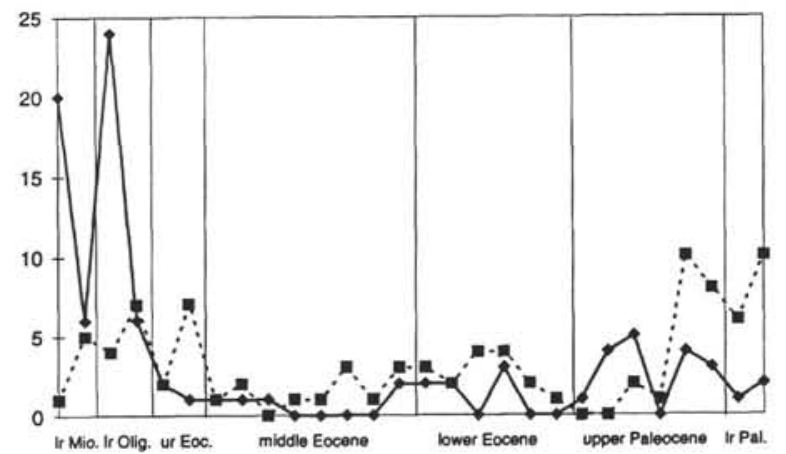

Figure 2. Faunal analysis of Ostracoda from Hole 865B. A. Number of specimens (abundance). B. Simple species diversity (number of species). Solid line indicates recorded taxa + Lazarus taxa; dotted line indicates recorded diversity only. C. Percentage of endemism (percentage of species endemic to this site). D. Number of originations (dotted line) and extinctions (solid line) that indicate faunal turnover. 
Table 1. Biostratigraphical distribution of Ostracoda recovered from Hole 865B.

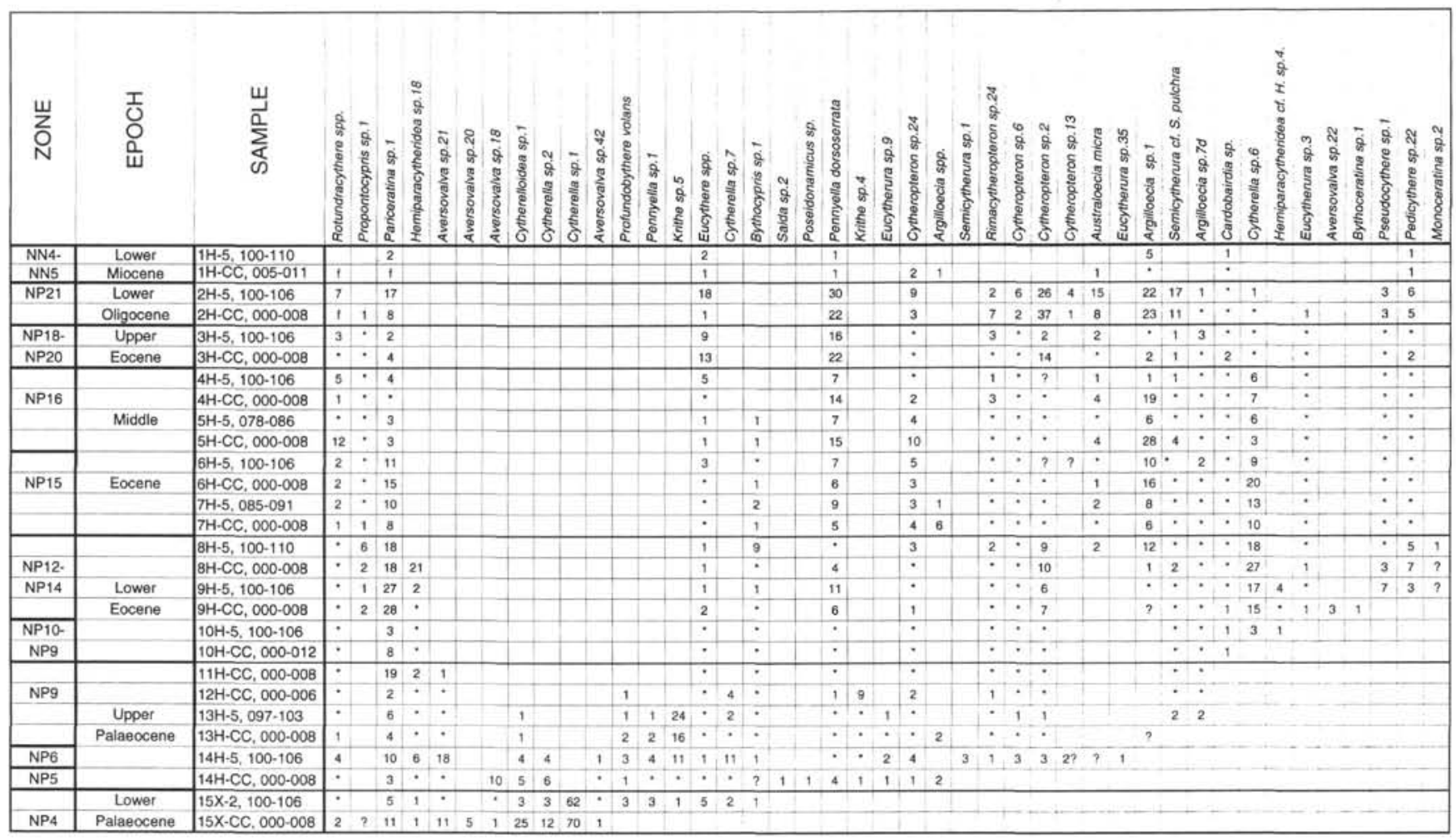

Note: Asterisk indicates temporarily absent or "Lazarus" record.

survived periods of dysaerobia better than other taxa (Whatley, 1990; Boomer and Whatley, 1993; Whatley and Arias, 1993). The gradual replacement of the Platycopina by Krithe may indicate that the adverse environmental conditions evident from the impoverished assemblages of the Paleocene/Eocene boundary interval may have included lowered oxygen levels, which would have allowed the Platycopina to dominate. The amelioration of environmental conditions subsequently resulted in Krithe thriving at the expense of the filter-feeding platycopids. Feeding strategy may also have benefited the platycopids during periods of upwelling over the guyot site as the supply of organic detritus increased.

\section{Upper Eocene-Lower Miocene}

This interval includes an Oligocene unconformity (Zones NP22 to NP25). Whatever factors brought about this event also resulted in a marked change in the Ostracoda. The steady increase in diversity, which occurs through the lower and middle Eocene, accelerates in the upper Eocene and lower Oligocene sections, as does the increase in abundance of Ostracoda. In this section (upper Eocene-lower Oligocene), one also sees a peak in the abundance of Krithe.

Sample 143-865B-2H-5, 100-106 cm, immediately below the unconformity, shows a marked extinction event (24 last appearances). Following the hiatus, diversity declined from 44 to 23 species, almost a $50 \%$ decrease. Abundances of Ostracoda also decline from about 650 to $<100$ individuals per sample. A similar sharp decline in species diversity is recorded later in the mid-Miocene Ostracoda assemblages from Horizon Guyot (Larwood and Whatley, 1993). Although the two events may well be linked, it appears that they were almost certainly not synchronous. It remains to be seen whether similar changes can be confidently traced in coeval sections from other Pacific guyots. Abundances of Ostracoda, diversity, and faunal turnover appear to be similar in both of the lower Miocene samples studied.

\section{FAUNAL SUMMARY OF HOLE 865B}

Rapidly changing assemblages resulted in three different groups (Platycopina, Krithe spp., and Pariceratina sp. 1) successively dominating the Paleocene-lowermost Eocene assemblages. From low abundance and low diversity assemblages of the Paleocene/Eocene boundary interval, diversity and abundance increase steadily throughout the lower and middle Eocene and accelerate in the upper Eocene and lower Oligocene. This period also indicates an increase in the percentage of abundance of Krithe that is mirrored by a decrease in the percentage of abundance of Platycopina. Marked faunal turnover and a diversity crash are apparent between the lower Oligocene and the lower Miocene sequences (the upper Oligocene being absent).

\section{SITE 866}

Hole $866 \mathrm{~B}$ is located on the summit of Huevo Guyot $\left(21^{\circ} 19.95^{\prime} \mathrm{N}\right.$, $174^{\circ} 18.87^{\prime} \mathrm{E}$, Fig. 1). The pelagic cap recovered was relatively thin and consists of $23.5 \mathrm{~m}$ of winnowed and reworked sediments that contain iron-manganese micronodules. Nannofossil and foraminiferal biostratigraphies of these pelagic sediments indicate an age range of lower Paleocene to Quaternary, with several unconformities; reworking is apparent. Notwithstanding this poor biostratigraphical control, the stratigraphical distribution of the Ostracoda is presented in Table 2 .

\section{FAUNAL EVOLUTION OF THE OSTRACODA AT HOLE 866B}

This short sequence consists of two distinct intervals: the lower part (from Samples 143-866B-2M-3, 100-110 cm, to $3 \mathrm{M}-\mathrm{CC}$ ) is mixed Paleocene to Eocene in age, based on foraminifers and nannofossils, whereas the upper part is Quaternary and possibly Pliocene in 
Table 1 (continued).

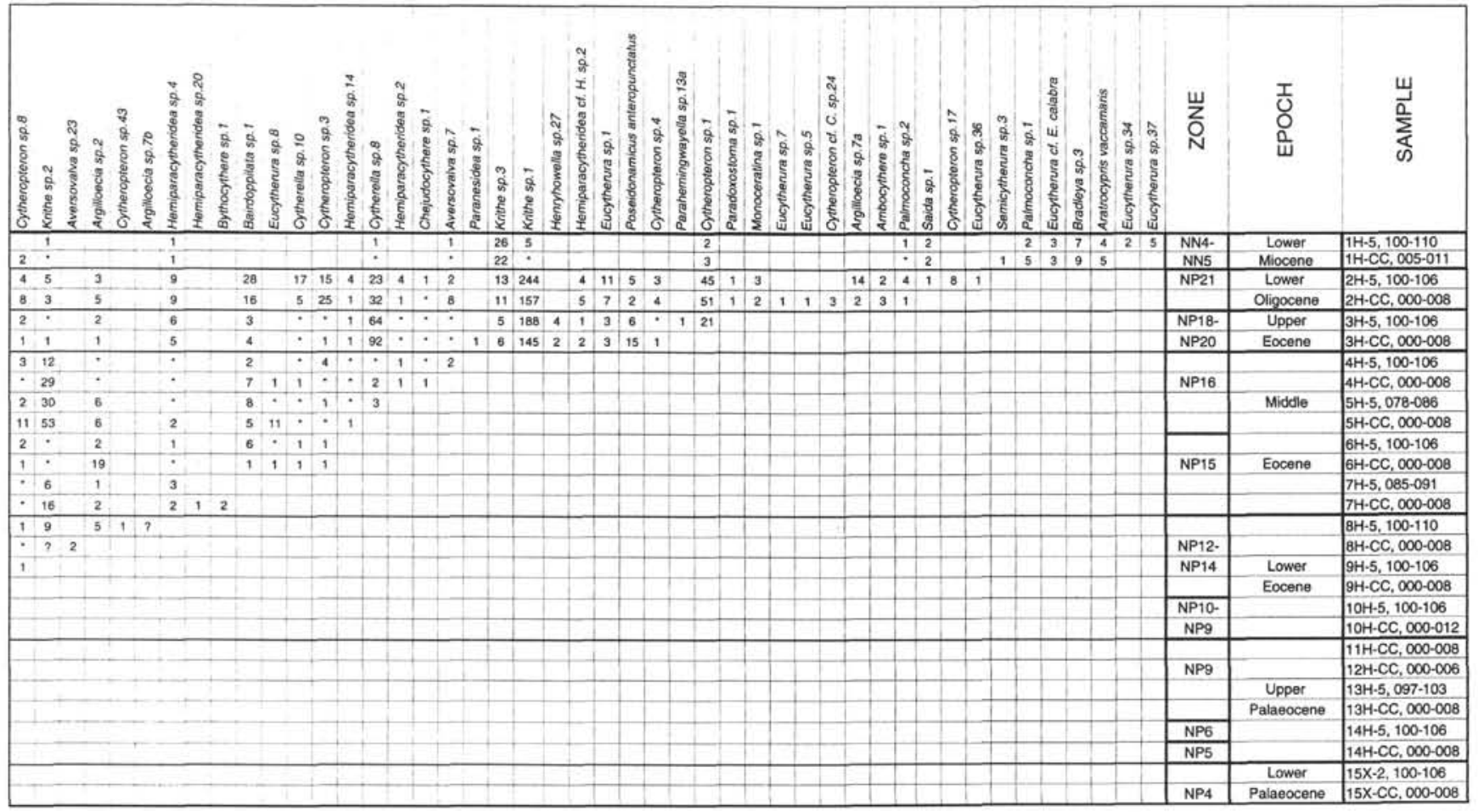

Table 2. Biostratigraphical distribution of Ostracoda recovered from Hole 866B.

\begin{tabular}{|c|c|c|c|c|c|c|c|c|c|c|c|c|c|c|c|c|c|c|c|c|c|c|c|c|c|c|c|c|c|c|c|c|c|c|c|}
\hline $\begin{array}{l}\frac{I}{U} \\
0 \\
0 \\
\text { ய }\end{array}$ & 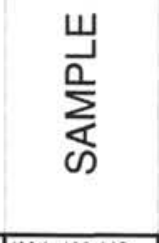 & 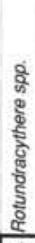 & 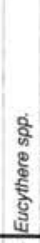 & 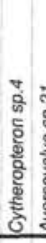 & 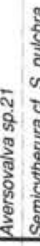 & & & 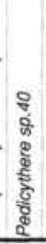 & 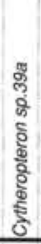 & 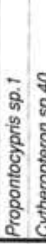 & & 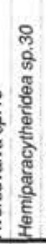 & $\begin{array}{l}0 \\
0 \\
0 \\
0 \\
0 \\
5 \\
5\end{array}$ & & & & 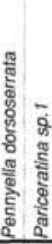 & & $=$ & 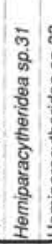 & 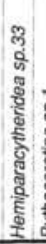 & 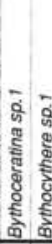 & 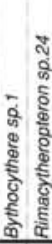 & 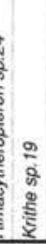 & 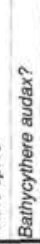 & 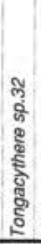 & 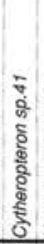 & 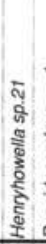 & & 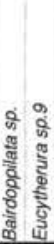 & $\begin{array}{l}\frac{2}{0} \\
0 \\
0 \\
\frac{5}{3} \\
\frac{5}{5} \\
\frac{5}{5} \\
\end{array}$ & 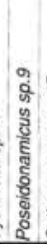 & 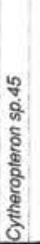 & $\begin{array}{l}\text { I } \\
\text { ல } \\
\text { ㅁ }\end{array}$ & 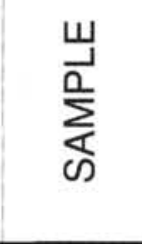 \\
\hline & $1 \mathrm{M}-1,100-110$ & 4 & 1 & & & & & & 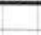 & 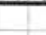 & & 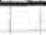 & - & - & - & - & 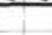 & 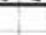 & & & & & & 42 & 3 & 2 & 9 & 1 & & & 7 & & & & $1 \mathrm{M}-1,100-110$ \\
\hline & $1 \mathrm{M}-2,100-106$ & ${ }^{\circ}$ & 2 & & & & & & & & & & & & & & & & & & & & & 38 & ${ }^{\circ}$ & 1 & $\cdot$ & $\cdot$ & 14 & & , & & 2 & & $1 \mathrm{M}-2,100-106$ \\
\hline \multirow[t]{4}{*}{ Quaternary } & $1 M-3,100-106$ & 2 & 1 & & & & & & & & & & & & & & 1 & & & & & & & 52 & . & 1 & 17 & 5 & 71 & +1 & 2 & 1 & & Quaternary & $1 \mathrm{M}-3,100-106$ \\
\hline & $1 M-4,100-110$ & 2 & 2 & & & & & & & & & & & & & & - & & & & & & & 39 & 1 & 1 & 8 & 5 & & & & & & & $1 M-4,100-110$ \\
\hline & IM-CC, $028-034$ & 3 & 2 & & & & & & & & & & & & & & 4 & & & & & & & 36 & 31 & 1 & 5 & 9 & & & & & & & 1M-CC, $028-034$ \\
\hline & $2 M-3,100-110$ & $\circ$ & $\cdot$ & & & & & & 1 & & & & & & & & $\cdot 12$ & 2 & & & & & & 1 & & & & & & & & & & & $2 M-3,100-110$ \\
\hline Mixed & 2M-CC, 009-015 & $\cdot$ & $\cdot$ & & & & 1 & 1 & $\cdot$ & & & & & & & & - 8 & 8 & & & 1 & & & & & & & & & & & & & Mixed & 2M-CC, $009 \cdot 015$ \\
\hline Palaeocene - & $3 M-3,100-106$ & . & • & & & & $\cdot$ & 7 & 29 & 3 & & & & & 1 & $?$ & 945 & 15 & & 12 & $3:$ & 2 & 1 & & & & & & & & & & & Palaeocene & 3М-3, 100-106 \\
\hline \multirow[t]{3}{*}{ Eocene } & $3 M-4,100-106$ & $\cdot$ & $\cdot$ & & & 1 & $\cdot$ & 3 & 10 & 2 & & & & & $\cdot$ & 26 & 622 & 2 & & 5 & $\cdot$ & $\cdot 1$ & 11 & & & & & & & & & & & Eocene & $3 M-4,100-106$ \\
\hline & $3 M-5,100-106$ & 1 & 1 & & & • & $\cdot$ & 10 & 42 & 3 & & 1 & & & $\cdot 1$ & 105 & 541 & 11 & & 17 & $1:$ & 33 & 3 & & & & & & & & & & & & $3 M-5,100-106$ \\
\hline & 3 M-CC, $006-012$ & 3 & 1 & 1 & 2 & 3 & 4 & 3 & 4 & 14 & 43 & 5 & 4 & 32 & 2, & 10 & $\begin{array}{ll}5 & 18 \\
\end{array}$ & 182 & 2 & & & & & & & & & & & & & & & & $3 \mathrm{M}-\mathrm{CC}, 006-012$ \\
\hline
\end{tabular}

Note: Asterisk indicates temporarily absent or "Lazarus" record.

age, based on the Ostracoda assemblages; the two intervals are faunally distinct.

\section{Paleocene-Eocene Mixed Assemblage}

The Paleocene-Eocene interval begins with a highly diverse assemblage dominated by cytherurid taxa (see Table 2). Many of these species do not occur any higher in the sequence, as reflected by the high extinction rate in the lowest sample (Fig. 4D). Diversity (Fig. 4B) and abundance (Fig. 4A) steadily decline through this interval, although endemism remains steady at between $30 \%$ and $50 \%$. Decreasing diversity was accompanied by steady extinction and low origination rates, which are mirrored by increasing dominance values $(25 \%-$ $85 \%$, Fig. 5A). The most abundant species is generally Pariceratina sp. 1 (Fig. 5D), which peaks in abundance at the lowest abundance and diversity values, similar to the Paleocene/Eocene boundary interval of Hole 865B. Krithe is only rarely recorded in this interval $(<10 \%$, Fig. $5 \mathrm{C}$ ), whereas the Platycopina are present in the lowest four samples and gradually decrease in abundance (always $<15 \%$ ). The Platycopina then recur in the topmost three Quaternary samples (Fig. 5B). 
A

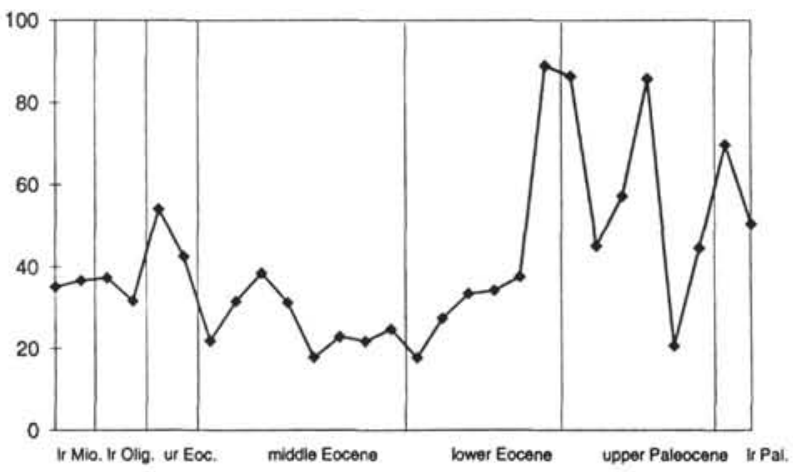

B

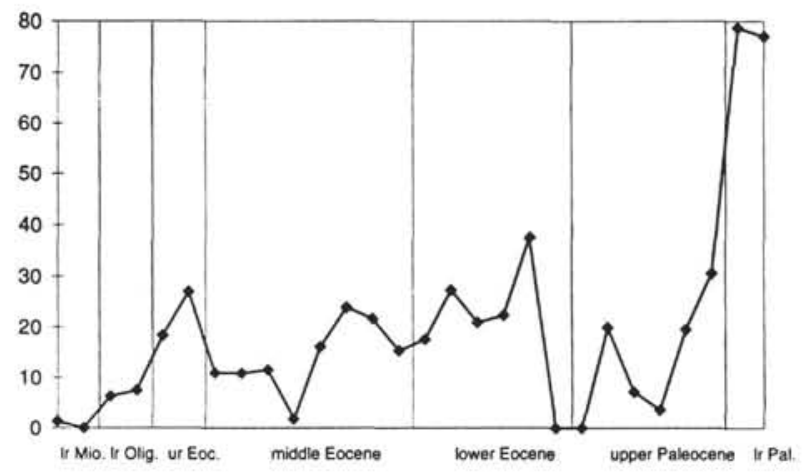

C

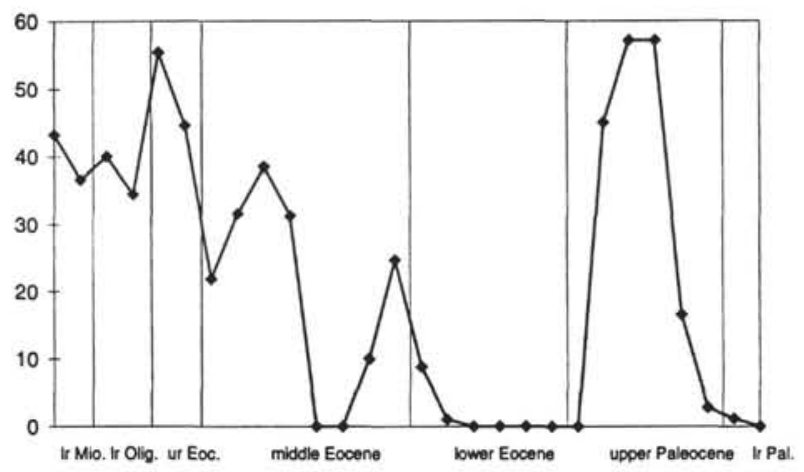

D

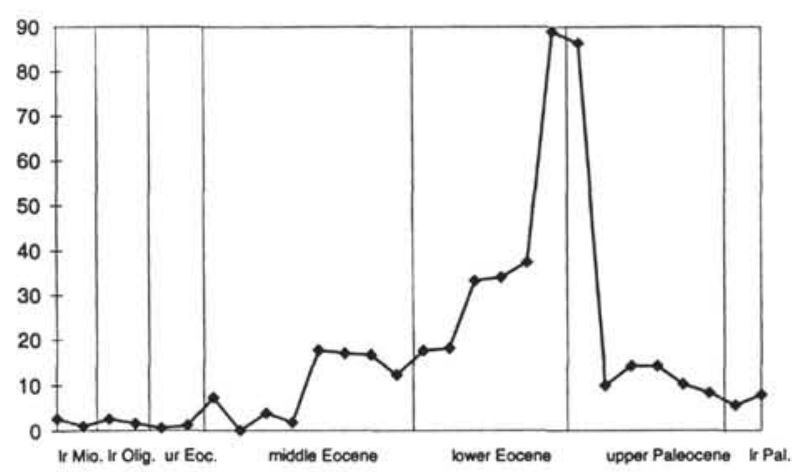

Figure 3. Faunal analysis of Ostracoda from Hole 865B. A. Dominance (percentage constituted by the most abundant species). B. Percentage of Platycopina (percentage of Platycopina individuals in the sample). C. Percentage of Krithe (percentage of Krithe individuals in the sample). D. Percentage of Pariceratina (percentage of Pariceratina individuals in the sample).

\section{Quaternary}

The Quaternary samples are characterized by relatively stable diversity, abundance, and dominance, with the latter being notably high at about $60 \%$. Endemism increases steadily in this interval to peak at 70\% (Sample 143-866B-1M-2, 100-106 cm). Pariceratina sp.1 was not recorded in the Quaternary samples; indeed, from the extensive collections of deep-sea Ostracoda examined at the University of Wales, Aberystwyth, it is not known from sediments younger than Miocene in the Pacific. Krithe, which dominates the assemblages in this part of the sequence, is represented by a single species, Krithe sp.19.

\section{BIOSTRATIGRAPHY OF OSTRACODA FROM HOLES 865B AND 866B}

Because of their benthic habit, the distribution of podocopid Ostracoda is highly dependent upon ambient environmental parameters. The Ostracoda are not always of value in biostratigraphical correlation, as is seen in the present study, because many of the taxa are endemic and migration appears restricted and opportunistic. Some taxa, particularly those belonging to the cytherurid genera Eucytherura, Cytheropteron, and Hemiparacytheridea, are represented by both endemic and a few regional or global pandemic species. Further taxonomic work on many of these cytherurid taxa is in progress (Ayress, pers. comm., 1993), and some of these taxa may subsequently prove to be of stratigraphical value. It has not been possible to provide strong correlation between the two ODP guyot sites using Ostracoda. At present, we do not intend to comment on the biostratigraphical details of these assemblages other than to present the range charts in Tables 1 and 2. Many of the taxa are illustrated in Plates 1 through 4.

\section{CONCLUSIONS}

The Ostracoda recovered from these two sites have added to our existing knowledge of the Cenozoic Pacific Ocean deep-sea fauna. Investigation of these new sites has reinforced preliminary findings that endemism levels are higher on guyots than elsewhere in the deep seas of this region.

Some degree of faunal instability was observed in the early Cenozoic assemblages. Following the initial drowning phase, a low-diversity and low-abundance "event" occurs in the upper Paleocene to lower Eocene. Samples in this interval are typically dominated by Pariceratina sp.1, which must have enjoyed some advantage over contemporaneous species. Indeed, this species appears both widespread and longranging in the Cenozoic of the Indo-Pacific region. Another species that is pandemic, long-ranging, and occurs in most of the samples investigated is Pennyella dorsoserrata (Brady, 1880). The majority of taxa encountered in the present study, however, appear to be stratigraphically and geographically short ranging.

Assemblage diversity increases steadily from the lower Eocene, with evidence that a second, possibly regional, event caused a diversity crash during the Oligocene to Miocene. Krithe is abundant from the upper Eocene to Miocene at Site 865 and exhibits low diversity; moreover, in cases where more than one species of Krithe occurs in a sample, one species is overwhelmingly dominant. The high degree of endemism means that few species can be used for biostratigraphic correlation. Significant paleoceanographical events, however, are reflected in the evolution of the Ostracoda.

Migration of benthic Ostracoda onto and between guyots undoubtedly occurred during the Cenozoic (Larwood and Whatley, 1993). Similarities are observed between these Cenozoic Pacific assemblages and elements of the Upper Cretaceous faunas described from Western Australia (Neale, 1975). The southwestern Pacific Ocean has previously been identified as a center of evolution for many deep-sea genera (Whatley, 1987). As more information becomes available from deep-sea sites, it may be possible to infer variations in the depth of the 
A

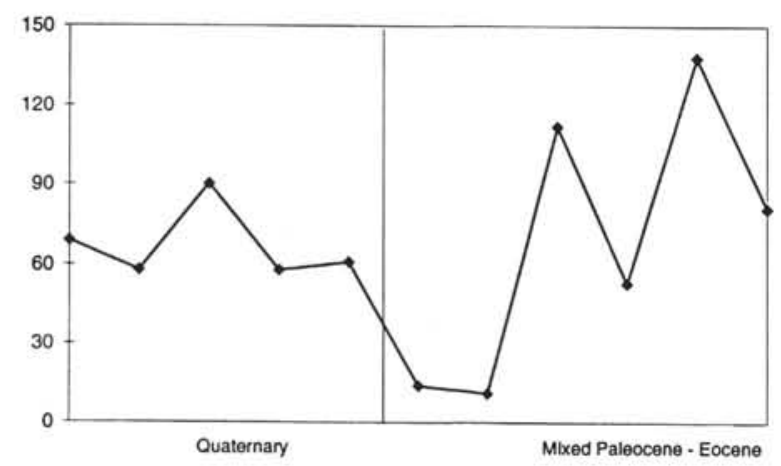

B

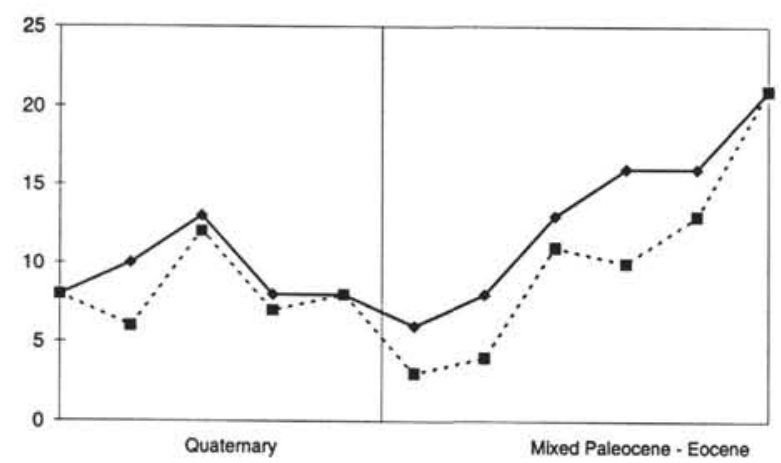

C

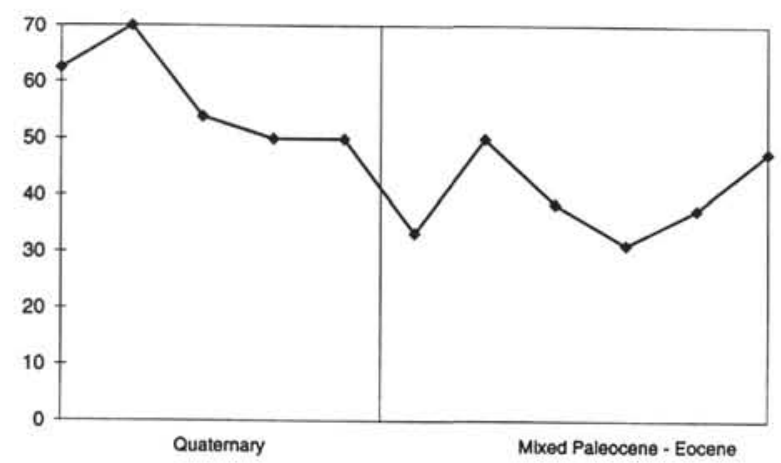

D

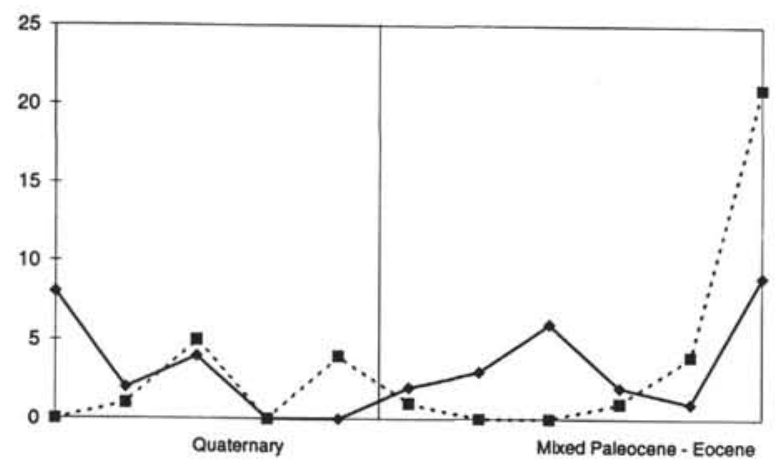

Figure 4. Faunal analysis of Ostracoda from Hole 866B. A. Number of specimens (abundance). B. Simple species diversity (number of species). Solid line indicates recorded taxa + Lazarus taxa; dotted line indicates recorded diversity only. C. Percentage of endemism (percentage of species endemic to this site). D. Number of originations (dotted line) and extinctions (solid line) that indicate faunal turnover.
A

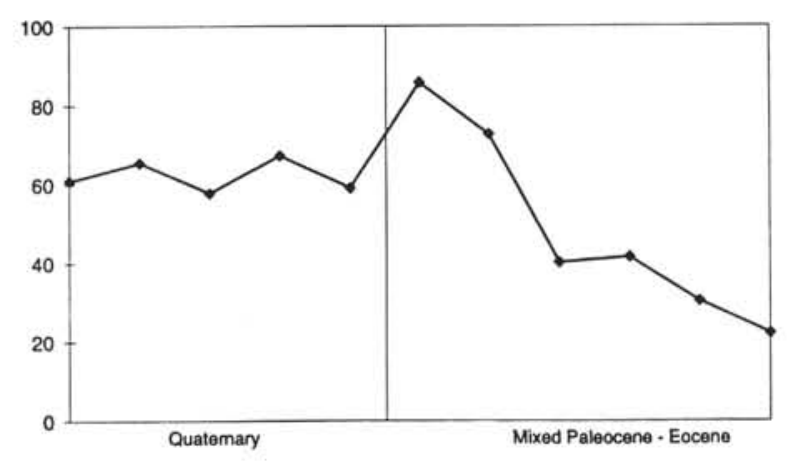

B

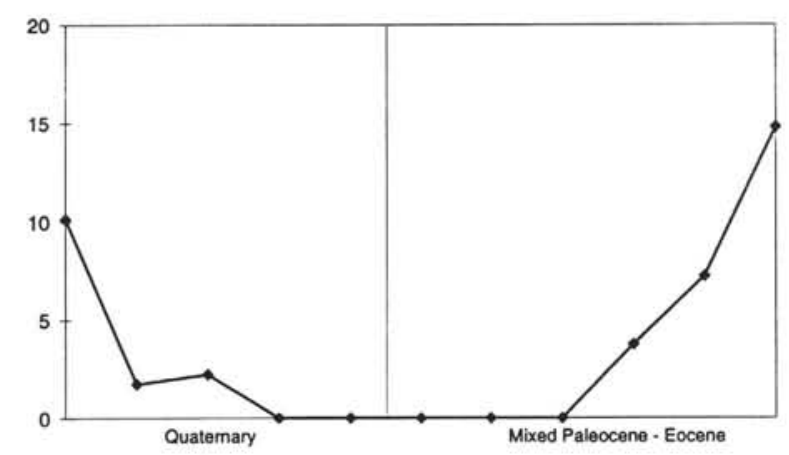

C

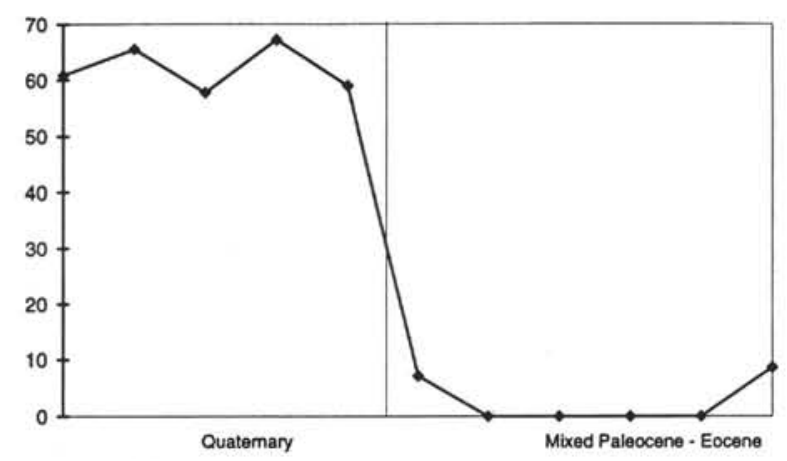

D

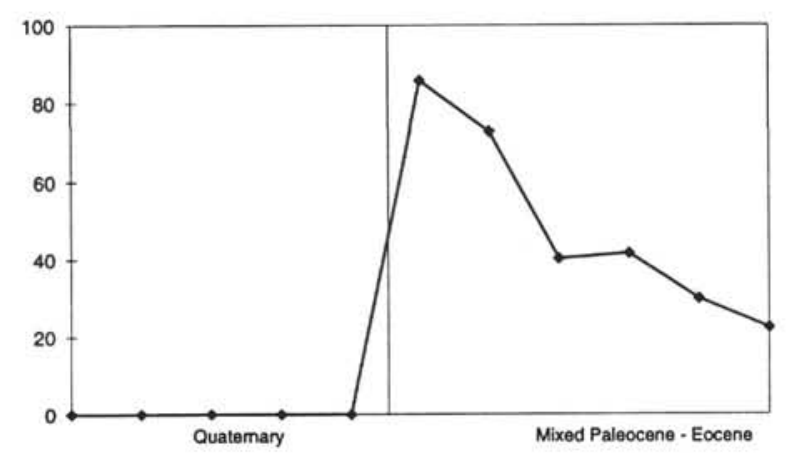

Figure 5. Faunal analysis of Ostracoda from Hole 866B. A. Dominance (percentage constituted by the most abundant species). B. Percentage of Platycopina (percentage of Platycopina individuals in the sample). C. Percentage of Krithe (percentage of Krithe individuals in the sample). D. Percentage of Pariceratina (percentage of Pariceratina individuals in the sample). 
lysocline in this region, as well as to determine the direction of ambient bottom currents.

\section{ACKNOWLEDGMENTS}

The authors acknowledge the tenure of a NERC ODP grant during this research. We thank Richard Jones (UWA) for tireless assistance with preparation and photographing many of these samples. We acknowledge David Griffiths (UWA) for his photographic skills.

\section{REFERENCES*}

Ainsworth, N.R., 1982. The biostratigraphy and palaeoecology of the Miocene and Pliocene Ostracoda of the Northern Indian Ocean [M.S. thesis]. University College, Wales.

Ayress, M., 1988. Late Pliocene to Quaternary deep-sea Ostracoda from the Eastern Indian and Southwestern Pacific Oceans [Ph.D. dissert.]. University College, Wales.

Benson, R.H., 1975. The origin of the psychrosphere as recorded in changes of deep-sea ostracode assemblages. Lethaia, 8:69-83.

Boomer, I.D., and Whatley, R.C., 1992. Ostracoda and dysaerobia in the Lower Jurassic of Wales: the reconstruction of past oxygen levels. Palaeogeogr., Palaeoclimatol., Palaeoecol., 99:373-379.

Brady, G.S., 1880. Report on the Ostracoda dredged by HMS Challenger during the years 1873-76. Rep. Sci. Results of the Voyage of HMS Challenger during the years 1873-76, Zoology, 3:1-184.

Coles, G., Ayress, M., and Whatley, R.C., 1990. Acomparison of North Atlantic and Pacific Cenozoic deep-sea Ostracoda. In Whatley, R.C., and Maybury, C. (Eds.), Ostracoda and Global Events: London (Chapman and Hall), 287-306.

Dainty, E.J., 1984. Pleistocene Ostracoda from four DSDP Sites of the SouthWest Pacific [M.S. thesis]. University College, Wales.

Dingle, R.V., Lord, A.R., and Boomer, I.D., 1990. Deep-water Quaternary Ostracoda from the continental margin off south-western Africa (SE Atlantic Ocean). Ann. S. Afr. Mus., 99:245-366.

Downing, S.E., 1985. The taxonomy, palaeoecology, biostratigraphy and evolution of Pliocene Ostracoda from the W. Pacific [Ph.D. dissert.]. University College, Wales.

Eldholm, O., and Thomas, E., 1993. Environmental impact of volcanic margin formation. Earth Planet. Sci. Lett., 117:319-329.

Larwood, J.G., and Whatley, R.C., 1993. Tertiary to Recent evolution of Ostracoda in isolation on seamounts. In McKenzie, K.G., and Jones, P. (Eds.), Ostracoda in the Earth and Life Sciences: 531-549.

Miller, K.G.,Janecek, T.R., Katz, M.E., and Keil, D.J., 1987. Abyssal circulation and benthic foraminiferal changes near the Paleocene/Eocene boundary. Paleoceanography, 2:741-761.

Millson, K.J., 1987. The palaeobiology of Paleogene Ostracoda from the Deep Sea Drilling Project in the South West Pacific [Ph.D. dissert.]. University College, Wales.

Neale, J.W., 1975. The ostracod fauna from the Santonian chalk (Upper Cretaceous) of Gingin, Western Austraila. Spec. Pap. Paleontol., 16:1-81.
Peypouquet, J., 1975. Les variations des caracteres morphologiques internes chez les Ostracodes des genres Krithe et Parakrithe: relation possible avec la teneur en dissous dans l'eau. Bull. Inst. Geol. Bassin Aquitain., 17:81-88. - 1977. Les ostracodes et la connaisance des paleomilieux profonds: Application au Cenozoique de l'Atlantique nord-oriental [ $\mathrm{Ph} . \mathrm{D}$. dissert.] Univ. de Bordeaux.

, 1979. Ostracodes et paleoenvironments. Methodology et application aux domaines profonds du Cenozoique. Fr. Bull. Bur. Rech. Geol. Min., Sec., 4:3-79.

Rea, D.K., Zachos, J.C., Owen, R.M., and Gingerich, P.D., 1990. Global change at the Paleocene-Eocene boundary: climatic and evolutionary consequences of tectonic events. Palaeogeogr., Palaeoclimatol., Palaeoecol., 79:117-128.

Smith, P.D., 1983. Quaternary deep sea ostracoda from the Southwest Pacific [M.S. thesis]. University College, Wales.

Thomas, E., 1990. Late Cretaceous-early Eocene mass extinctions in the deep sea. In Sharptin, V.L., and Ward, P.D. (Eds.), Global Catastrophes in Earth History: An Interdisciplinary Conference on Impacts, Volcanism, and Mass Mortality. Spec. Pap.-Geol. Soc. Am., 247:481-495.

, 1992. Cenozoic deep-sea circulation: evidence from deep-sea benthic foraminifera. In Kennett, J.P., and Warnke, D. (Eds.), The Antarctic Paleoenvironment: A Perspective on Global Change. Am. Geophys. Union, Antarct. Res. Ser., 56:141-165.

- in press. Mass extinctions in the deep sea. In Sharpton, V., and Ward, P. (Eds.), Proc. Conf. on Global Catastrophes in Earth History: An Interdisciplinary Conference on Impacts, Volcanism, and Mass Mortality. Spec. Pap.-Geol. Soc. Am., 247.

Whatley, R.C., 1987. The southern end of Tethys: an important locus for the origin and evolution of both deep and shallow water Ostracoda. In McKenzie, K.G. (Ed.), Shallow Tethys 2: Rotterdam (A.A. Balkema), 461-475.

, 1990. The Platycopid signal: a means of detecting kenoxic events using Ostracoda. J. Micropalaeontol., 10:181-183.

Whatley, R.C., and Arias, C.F., 1993. Paleogene Ostracoda from the Tripoli Basin Libya. Rev. Esp. Micropaleontol., 25:125-154.

Whatley, R.C., and Ayress, M.A., 1988. Pandemic and endemic distribution patterns in Quaternary deep-sea Ostracoda. In Hanai, T., Ikeya, N., and Ishizaki, K. (Eds.), Evolutionary Biology of Ostracoda: Its Fundamentals and Applications: Amsterdam (Elsevier), 739-755.

Whatley, R.C., Downing, S.E., Kesler, K., and Harlow, C.J., 1984. New species of the ostracod genus Bradleya from the Tertiary and Quaternary of D.S.D.P. sites in the Southwest Pacific. Rev. Esp. Micropaleontol., 16:265-298.

, 1986. The ostracode genus Poseidonamicus from the Cenozoic of DSDP sites in the SW Pacific. Rev. Esp. Micropaleontol., 18:387-400.

Abbreviations for names of organizations and publications in ODP reference lists follow
the style given in Chemical Abstracts Service Source Index (published by American
Chemical Society).

Date of initial receipt: 8 November 1993

Date of acceptance: 14 March 1994

Ms 143SR-249 


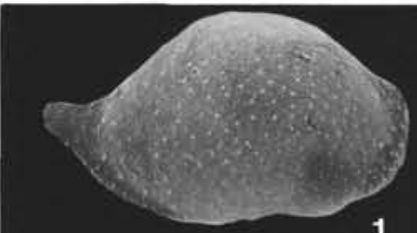

1

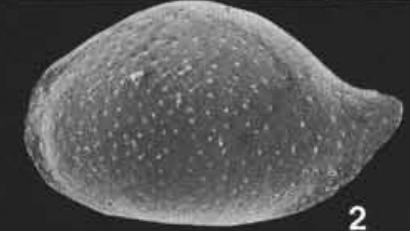

2

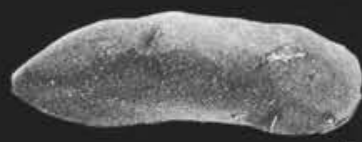

5

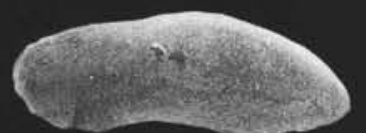

6

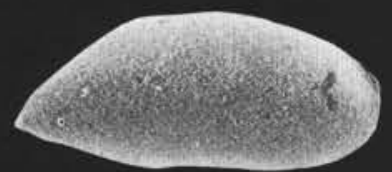

10
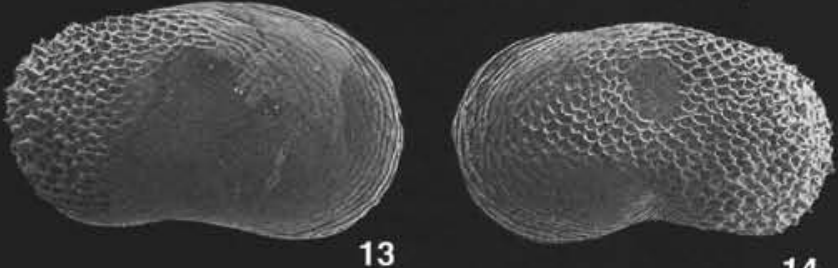

14

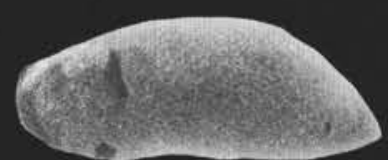

11

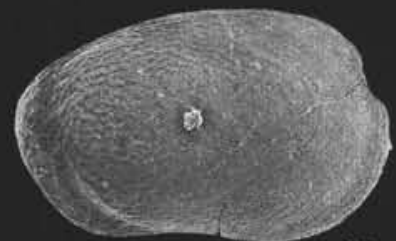

15

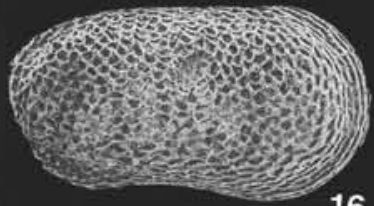

16
17

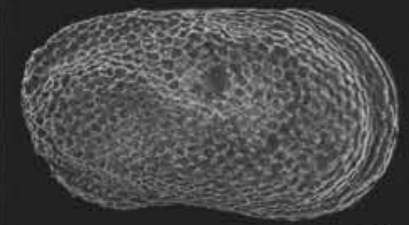

21

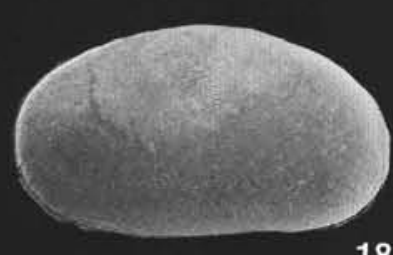

18

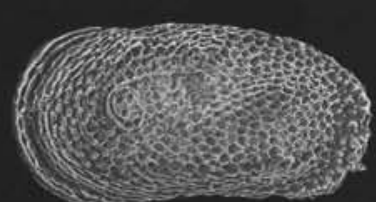

22

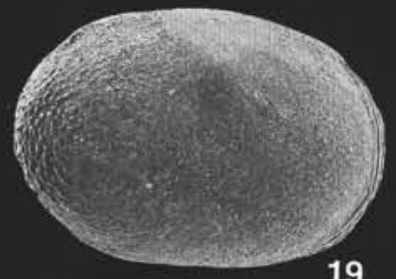

19

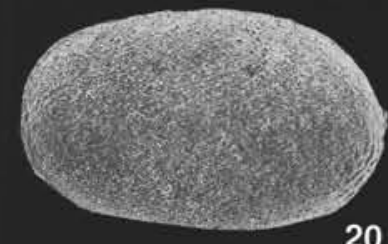

20

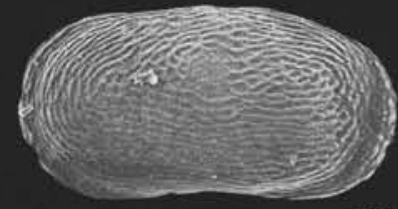

23

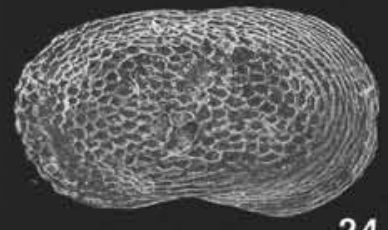

Plate 1. 1, 2. Bairdoppilata sp. 1; Sample 143-865B-3H-CC, 0-8 cm (1) RV $\times 31$ (2) LV $\times 34$. 3, 4. Aratrocypris vaccamaris; Sample 143-865B-1H-CC, 5-11 cm (3) RV $\times 81$ (4) LV $\times 85$. 5, 6. Argilloecia sp. 2; Sample 143-865B-6H-CC, 0-8 cm, $\times 61$ (5) RV (6) LV. 7. Argilloecia sp. 7a; Sample 143-865B-2H-CC, 0-8 cm, RV $\times 56$. 8. Australoecia micra; Sample 143-865B-2H-CC, 0- $8 \mathrm{~cm}$, Carapace, left lateral, $\times 81$. 9. Cytherelloidea sp. 1; Sample 143-865B-15X-CC, 0-8 cm, LV $\times 50$. 10, 11. Argilloecia sp. 1; Sample 143-865B-6H-CC, 0-8 cm, $\times 67$ (10) RV (11) LV. 12. Propontocypris sp. 1; Sample 143-865B-9H-CC, 0-8 cm, LV $\times 100$. 13, 14. Cytherella sp. 8; Sample 143-865B-3H-CC, 0-8 cm, $\times 48$ (13) RV (14) LV. 15. Cytherella sp. 2; Sample 143-865B-15X-CC, 0-8 $\mathrm{cm}, \mathrm{RV} \times 53$. 16, 24. Cytherella sp. 7; (16) Sample 143-865B-9H-CC, 0- $8 \mathrm{~cm}$, Male RV $\times 50$ (24) Sample 143-865B-12H-CC, $0-8 \mathrm{~cm}$, Female RV $\times 50$. 17, 18. Cytherella sp. 10; Sample 143-865B-2H-CC, 0-8 cm, $\times 29$ (17) RV, (18) LV. 19, 20. Cytherella sp. 1; Sample 143-865B-13H-CC, 0-8 cm, $\times 39$ (19) RV, (20) LV. 21,22. Cytherella sp. 6; Sample 143-865B-8H-CC, 0-8 cm (21) Female RV, $\times 54$, (22) Male LV, $\times 52$. 23. Cytherella sp. 11; Sample 143-866B-3M-CC, $6-12 \mathrm{~cm}, \mathrm{LV} \times 57$ 

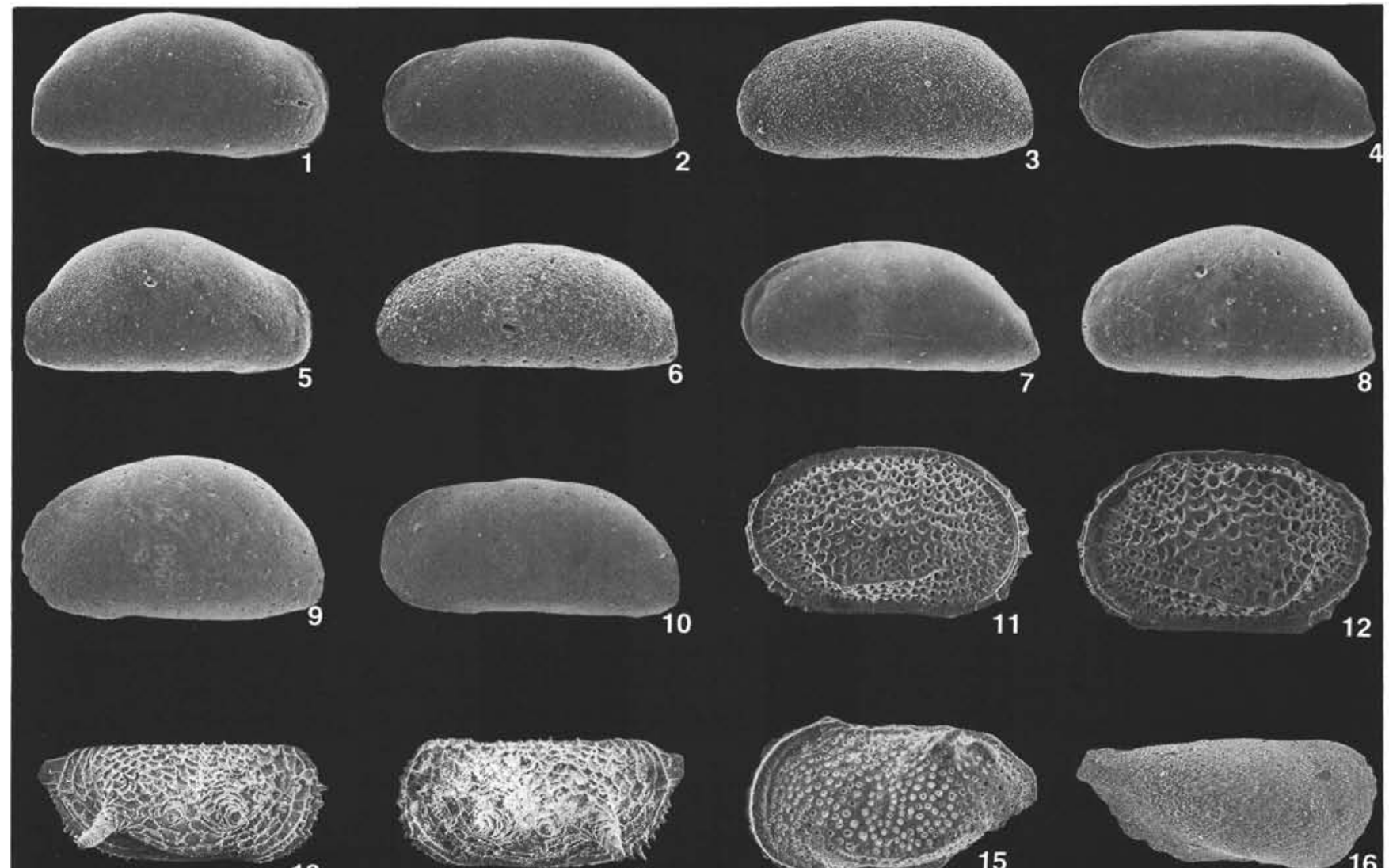

14
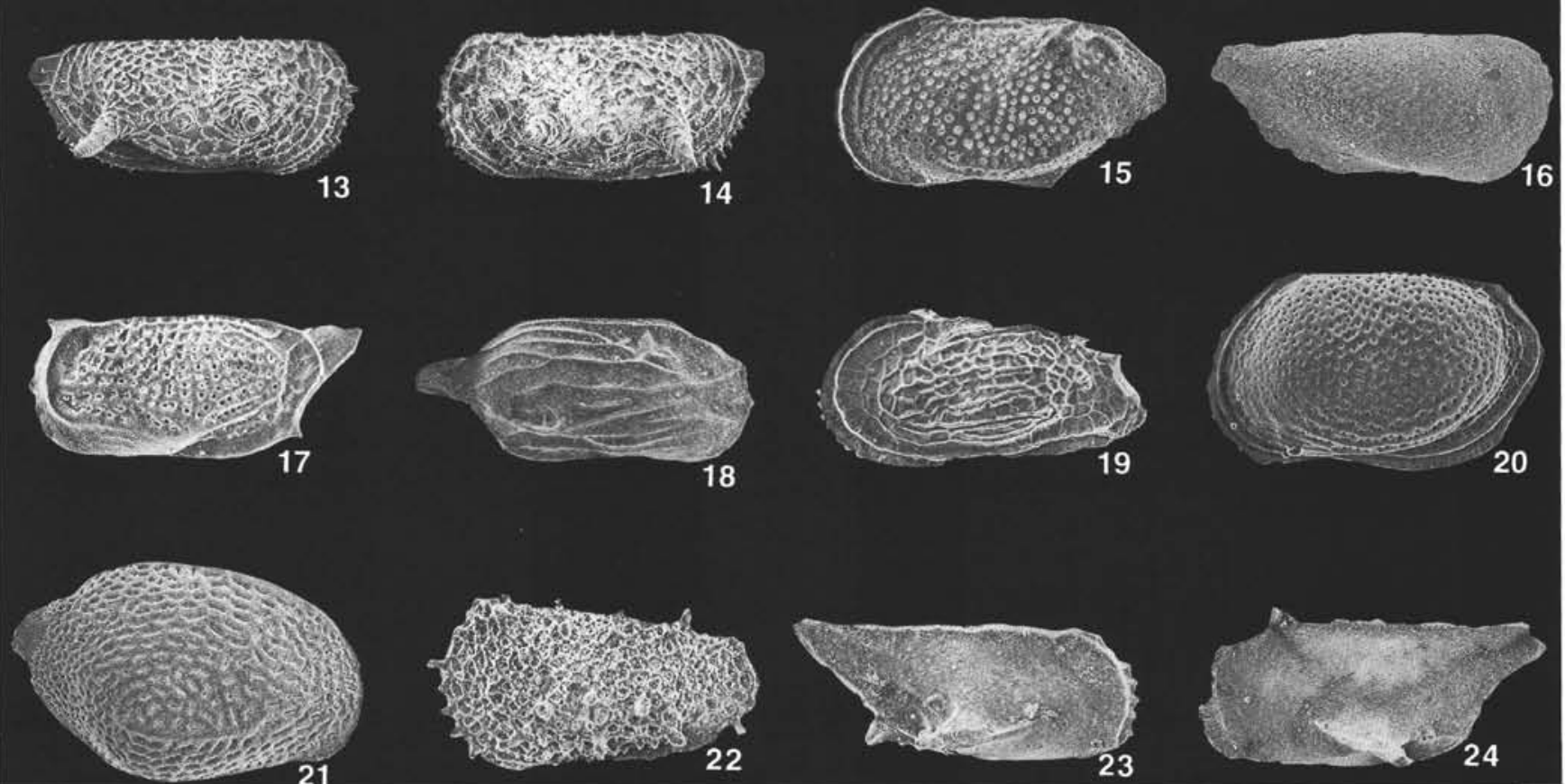

Plate 2. 1, 2. Krithe sp. 1; Sample 143-865B-2H-CC, 0-8 cm (1) RV $\times 47$ (2) LV $\times 38 . \quad 3$, 4. Krithe sp. 2; (3) Female LV, Sample 143-865B-2H-CC, 0-8 cm, $\times 51$ (4) Male LV, Sample 143-865B-5H-CC, 0-8 cm, $\times 50$. 5, 6. Krithe sp. 3; (5) Female RV, Sample 143-865B-1H-CC, 5- 11 cm, $\times 47$ (6) Male LV, Sample 143-865B-2H-CC, 0-8 cm ×45. 7, 8. Krithe sp. 5; Sample 143-865B-13H-CC, 0-8 cm, (7) RV $\times 43$ (8) LV $\times 47 . \quad$ 9, 10. Krithe sp. 19; Sample 143-866B1M-CC, 28-34 cm, (9) Female LV $\times 47$ (10) Male LV $\times 41$. 11, 12. Saida sp. 1; Sample 143-865B-1H-CC, 5-11 cm, (11) RV $\times 85(12)$ LV $\times 81 . \quad 13,14$. Pariceratina sp. 1; (13) RV, Sample 143-865B-11H-CC, $0-8 \mathrm{~cm}, \times 49$ (14) LV, Sample 143-865B-13H-CC, $0-8 \mathrm{~cm}, \times 49 . \quad$ 15. Profundobythere volans; Sample 143-865B-13H-CC, 0-8 cm, LV $\times 87$. 16. Pseudocythere sp. 1; Sample 143-865B-2H-CC, 0-8 cm, RV $\times 74$. 17. Semicytherura cf. S. pulchra; Sample 143-865B-5H-CC, 0-8 cm, LV $\times 95$. 18. Semicytherura sp. 3; Sample 143-865B-11H-CC, 5-11 cm, RV $\times 93$. 19. Ambocythere sp. 1; Sample 143-865B2H-CC, 0-8 cm, LV $\times 59$. 20. Palmoconcha sp. 1; Sample 143-865B-1H-CC, 5-11 cm, LV $\times 72$. 21. Rimacytheropteron sp. 24; Sample 143-865B-2H-CC, 0-8 cm, RV $\times 85$. 22. Eucytherura sp. 9; Sample 143-865B-14H-CC, $0-8 \mathrm{~cm}, \mathrm{LV} \times 89$. 23. Pedicythere sp. 22; Sample $143-865 \mathrm{~B}-3 \mathrm{H}-\mathrm{CC}, 0-8 \mathrm{~cm}, \mathrm{RV} \times 78$. 24. Pedicythere sp. 40; Sample 143-866B-3M-CC, 6-12 cm, LV $\times 85$. 

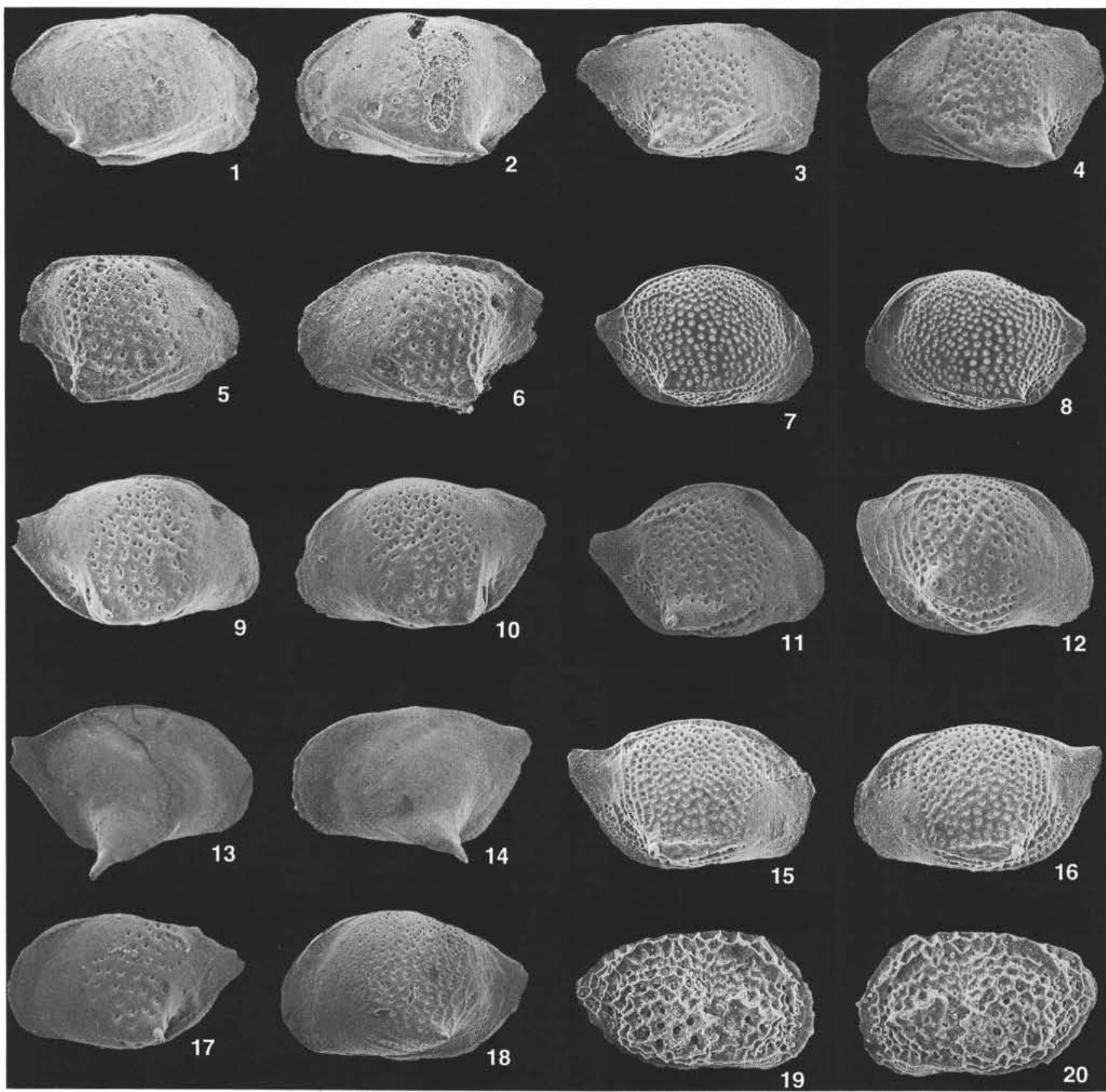

Plate 3. 1, 2. Cytheropteron sp. 8; Sample 143-865B-2H-CC, 0-8 cm (1) RV $\times 91$ (2) LV $\times 88 . \quad 3$, 4. Aversovalva sp. 7; Sample 143-865B-2H-CC, 0-8 cm (3) RV $\times 91$ (4) LV $\times 80$. 5, 6. Aversovalva sp. 21; Sample 143-865B-15X-CC, 0-8 cm, $\times 109$ (5) RV (6) LV. 7, 8. Cytheropteron sp. 41; Sample 143-866B-1M-CC, 28-34 cm, $\times 71$ (7) RV (8) LV. 9, 10. Cytheropteron sp. 3; Sample 143-865B-2H-CC, 0-8 cm, $\times 94$ (9) RV (10) LV. 11. Cytheropteron sp. 6; Sample 143-865B-2H-CC, 0-8 cm, RV $\times 74$. 12. Cytheropteron sp. 4; Sample 143-865B-2H-CC, 0-8 cm, RV $\times 74 . \quad 13$, 14. Cytheropteron sp. 2; Sample 143-865B-2H-CC, 0-8 cm (13) RV $\times 47$ (14) LV $\times 51$. 15, 16. Cytheropteron sp. 24; Sample 143-865B-6H-CC, $0-8 \mathrm{~cm}, \times 76$ (15) RV (16) LV. 17. Cytheropteron sp. 25; Sample 143-865B-4H-CC, 0-8 cm, LV $\times 87 . \quad$ 18. Cytheropteron sp. 1; Sample 143-865B-2H-CC, 0-8 cm, $\times 74$ (17) RV (18) LV. 19, 20. Eucytherura sp. 8; Sample 143-865B-5H-CC, 0-8 cm, $\times 121$ (21) RV (22) LV. 

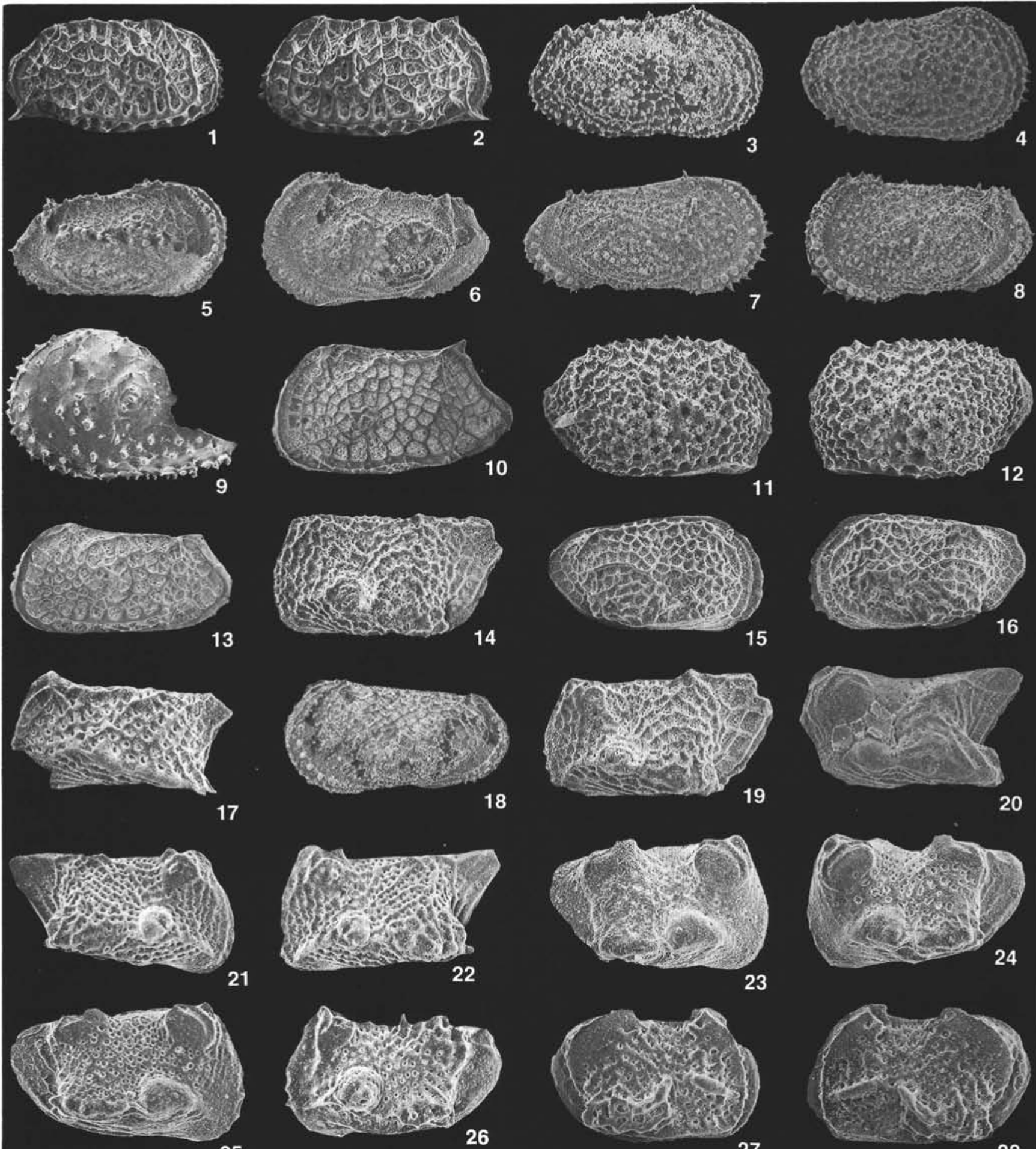

23
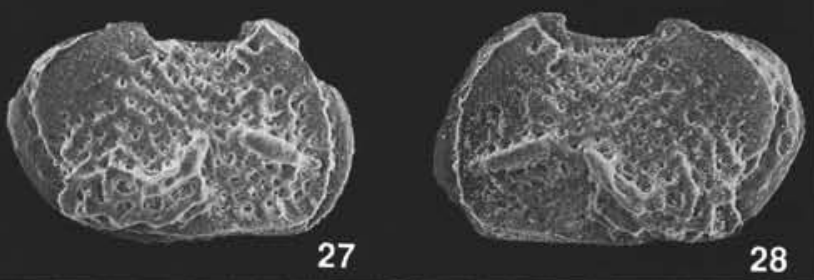

Plate 4. 1, 2. Bradleya sp. 3; Sample 143-865B-1H-CC, 5-11 cm, $\times 43$ (1) RV (2) LV. 3. Henryhowella sp. 21; Sample 143-866B-1M-CC, 28-34 cm, RV $\times 48$. 4. Henryhowella sp. 27 ; Sample $143-865 \mathrm{~B}-3 \mathrm{H}-\mathrm{CC}, 0-8 \mathrm{~cm}$, RV $\times 64$. 5, 6. Pennyella sp. 1 ; (5) RV, Sample $143-865 \mathrm{~B}-13 \mathrm{H}-\mathrm{CC}, 0-8 \mathrm{~cm}, \times 54$ (6) LV, Sample 143-865B-14H-CC, $0-8 \mathrm{~cm}, \times 54$. 7, 8. Pennyella dorsoserrata; (7) RV, Sample 143-865B-8H-CC, 0-8 cm, $\times 57$ (8) LV, Sample 143-865B-5H-CC, 0-8 cm, $\times 59$. 9. Bathycythere audax?; Sample 143-866B-1M-CC, $28-34 \mathrm{~cm}$, LV fragment $\times 47$. 10. Tongacythere sp. 32; Sample 143-866B-1M-CC, 28-34 $\mathrm{cm}, \mathrm{LV} \times 38$. 11, 12. Eucytherura cf. E. calabra; Sample 143-865B-1H-CC, $5-11 \mathrm{~cm}, \times 111$ (11) RV (12) LV. 13. Poseidonamicus anteropunctatus; Sample 143-865B-3H-CC, 0-8 cm, LV $\times 49$. 14. Hemiparacytheridea sp. 30; Sample 143-866B-3M-CC, 6-12 cm, LV $\times 102$. 15, 16. Eucytherura sp. 1; Sample 143-865B-2H-CC, 0-8 cm, $\times 111$ (15) RV (16) LV. 17. Hemiparacytheridea sp. 14; Sample 143-865B-2H-CC, 0-8 cm, LV $\times 93$. 18. Pennyella dorsoserrata; Sample 143-866B-1M-CC, $28-34 \mathrm{~cm}, \mathrm{LV} \times 47$. 19. Hemiparacytheridea $\mathrm{sp}$. 31; Sample 143-866B-2M-CC, 9-15 cm, LV $\times 102.20$. Hemiparacytheridea sp. 18; Sample 143-865B-15X-CC, 0-8 cm, LV $\times 102$. 21, 22. Hemiparacytheridea sp. 4; Sample 143-865B-2H-CC, 0-8 cm, $\times 102$ (21) RV (22) LV. 23, 24. Hemiparacytheridea sp. 2; Sample 143-865B-2H-CC, 0-8 cm, $\times 102$ (23) RV (24) LV. 25. Hemiparacytheridea sp. 21; Sample 143-865B-4H-CC, 0-8 $\mathrm{cm}, \mathrm{RV} \times 102$. 26. Eucytherura sp. 3; Sample 143-865B-2H-CC, $0-8 \mathrm{~cm}, \mathrm{LV} \times 111$. 27, 28. Eucytherura sp. 7; Sample 143-865B-2H-CC, 0-8 cm, $\times 111$ (27) RV (28) LV. 